\title{
Report
}

\section{Crossing Boundaries: Understanding Complex Scribal Practices in Ancient Egypt (with a 2019 Progress Report)}

Stéphane Polis*, Kathrin Gabler**, Christian Greco*** Elena Hertel** , Antonio Loprieno**, Matthias Müller**, Renaud Pietri*, Nathalie Sojic*, Susanne Töpfer*** and Stephan Unter**

*F.R.S.-FNRS / University of Liège ** University of Basel *** Museo Egizio, Turin

In this paper, we introduce the joint project of the Museo Egizio (Turin), the University of Basel, and the University of Liège entitled "Crossing Boundaries: Understanding Complex Scribal Practices in Ancient Egypt", and provide a progress report for 2019. The project deals with Ramesside hieratic papyri of the Turin collection that stem from Deir el-Medina (c. 1350-1050 BCE), adopting a contextualised approach to this written material. Crossing the boundaries between disciplines, we aim to shed light on the life of a particular category of complex documents, labelled "heterogeneous" papyri, i.e., papyri combining on a single support texts (or drawings) belonging to different genres.

$$
\begin{aligned}
& \text { في هذا النص، البحت: نقدم المشروع المشترك بين المتحف المصري (تورينو)، وجامعة بازل، وجامعة لييج بعنوان "تخطي الحدود: فهم } \\
& \text { طرق الكتابة المعقدة في مصر القديمة"، وتقديم تقرير لفترة عام 2019. يعمل الششروع على البردية الهير اطيقية لرمسيس } \\
& \text { المحفوظة ضمن مجموعة تورينو والتي تعود إلى دير المدينة (حوالي } 1350 \text { - } 1050 \text { قبل الميلاد)، ويتبنى منهجاً محدداً لهذا } \\
& \text { النص المكتوب. على وجه الخصوص، إز الة الحدود بين التخصصات المختلفة، نهدف إلى تسليط الضوء على حياة فئة معينة من } \\
& \text { الوثائق المعقدة، والتي تحمل علامات البرديات "غير المتجانسة"، أي البردية التي تحتوي على نصوص (أو رسومات) ذات } \\
& \text { طابع مختلف أو طبيعة مختلفة. }
\end{aligned}
$$

\section{Introduction}

Many aspects of ancient Egyptian scribal culture are still poorly understood. Earlier research mostly focused on the contents of texts in order to reconstruct literary compositions, explain historical events, or describe administrative and judicial customs. In trying to overcome traditional epistemological and methodological divides between disciplines such as archaeology, papyrology, palaeography, prosopography, and textual scholarship, the project "Crossing Boundaries" ${ }^{1}$ adopts an interdisciplinary approach to written material. We are interested in the scribal practices of the individual agents who produced texts and in the life history of a particular category of complex documents, which we have labelled "heterogeneous"; papyri, that is, on each of which are assembled texts or drawings ascribable to different genres, such as accounts, poems, hymns and letters. This category of papyri has never been studied as a coherent whole; rather, individual papyri have been used as convenient quarries for collecting additional witnesses of literary texts or specific pieces of information for thematic studies. They are, however, of primary importance for the study of the competence and performance of ancient scribes, both synchronically and diachronically.

"Crossing Boundaries" targets the rich papyrological material that stems from the village of Deir el-Medina, which housed the families of the workmen who built the royal tombs in the Valley of the Kings and the Valley of the Queens during the New Kingdom (c. 1350-1050 BCE). This highly literate community produced an unparalleled quantity of texts and inscriptions, and is undoubtedly the best laboratory 
to observe scribes at work in ancient Egypt. Building on existing collaborations between the Museo Egizio (Turin) - which holds the most important collection of papyri from this site ${ }^{2}-$, the University of Basel, and the University of Liège, the five main goals of this research project are to (1) identify and document the fragments of papyri in the Turin collection; (2) join these fragments and provide a digital reconstruction of the original documents; (3) study the variety of texts attested on each papyrus, assess the number of scribal hands, and suggest individual scenarios and generalisations concerning the history of these documents; (4) enrich the results with data coming from other ancient Egyptian archives of "heterogeneous" papyri from Deir el-Medina; (5) broaden the perspective by comparing, quantitatively and qualitatively, the data from Deir el-Medina with complex scribal practices of other periods and places in ancient Egypt.

\section{Project description}

In this section, we provide background information about contextualised approaches to writing in the community of Deir el-Medina (\$2.1.) and to the Ramesside papyrological material from the Museo Egizio (\$2.2.). This allows us to frame our research project on "heterogeneous" papyri (\$2.3.) more precisely, and to detail our research plan (\$2.4.).

\subsection{Contextualised approaches to Egyptian scribal practices: The situation of Deir el-Medina}

The quantity of written material coming from Deir el-Medina ${ }^{3}$ is considerable for two main reasons: ${ }^{4}$ on the one hand, the high level of literacy of the members of this community (who produced a significant amount of texts), ${ }^{5}$ on the other hand, the exceptional state of preservation of the material itself. The village is indeed located in foothills, protected from the Nile floods, and was abandoned sometime during the reign of Ramesses XI (c. 1100 BCE), when the community moved away, mainly because work in the royal necropolis had stopped and the desert was not a safe place at the time. ${ }^{6}$

This unparalleled archaeological site was exposed to looting for centuries, but when Bernard Bruyère began its systematic excavation in 1917 for the French
Institute for Oriental Archaeology in Cairo the sheer quantity of textual carriers (inter alia several thousand potsherds and limestone ostraca) prompted a partition of the material between two Egyptologists, Jaroslav Černý and Georges Posener. ${ }^{7}$ The former was to publish the texts dealing with administration and daily life, the latter the ostraca with literary, magical, and religious compositions in the broader sense. Born out of practical necessities, this partition of the material quickly led to a disciplinary schism. The administrative texts became the object of an independent branch of study, with foremost research centres like the universities of Leiden and Munich focusing on the economic, social and political history of the village and related prosopographical issues. The literary texts, on the other hand, were mostly used for their content, i.e., they were often resorted to as mere sources providing additional witnesses for reconstructing the original literary composition. ${ }^{8}$ Despite the fact that the same scribes were quite obviously behind these different texts and genres (not infrequently combined on the same papyrus), crossing the boundaries between the two realms became an exception.

As such, the main goal of the present project is to study scribal practices in "heterogeneous" documents (§2.3.) that blur the frontiers between these two somewhat artificially created domains: the time has come for a contextualised and interdisciplinary approach to this material that considers the documents in their entirety, sees them in relation to their archaeological and social contexts, ${ }^{9}$ and envisions the texts as productions of individual scribes to be interpreted both in relation to the other texts and drawings on the same document and to the larger intertextual environment. ${ }^{10}$

Three main developments in the field support this research orientation. Firstly, research on administrative scribal practices in Deir el-Medina ${ }^{11}$ has shown the vast potential of a contextualised approach to writing taking into account the archaeological data, the archival traditions, and the individual habits of scribes. ${ }^{12}$ Secondly, a few studies have advocated an interdisciplinary view of the material left by the necropolis workmen - taking a scribe ${ }^{13}$ or an archaeological site ${ }^{14}$ as a point of departure - and offered an entirely new perspective on old research topics. 
Finally, literary scholars ${ }^{15}$ have shown the benefits of an interdisciplinary perspective integrating all dimensions of a document, from the very materiality of the text-bearing object ${ }^{16}$ to the reconstructed situation of performance.

\subsection{The Ramesside papyrological material from Deir el-Medina in the Museo Egizio}

The Ramesside papyrological material in the Museo Egizio is an obvious candidate for experiments in this direction. Most of these papyri were acquired for the museum in 1824 by the king of Sardinia, purchasing them from Bernardino Drovetti (1776-1852), the French consul in Egypt at the time, whose agents procured most of the antiquities for his collection in western Thebes. Many of the Turin papyri mention matters regarding the construction of the royal tombs in the Valley of the Kings and the Valley of the Queens. Based on such pieces of evidence internal to the texts, most of the manuscripts in Turin can be inferred to have belonged to the administration of the royal necropolis and very likely originate from the village of Deir el-Medina. In addition to the Drovetti collection, the excavations of the Museo Egizio led by Ernesto Schiaparelli (1856-1928) in Deir el-Medina at the beginning of the twentieth century brought to light new papyri, which - based on joins that can be posited between them and those collected by Drovetti - confirm the latter's provenance. ${ }^{17}$

The Museo Egizio holds what is undoubtedly the largest papyrus archive from pre-Hellenistic times. ${ }^{18}$ The study of these papyri has been unflagging, ${ }^{19}$ but has also proved challenging from both a quantitative - about 9,000 fragments of Ramesside papyri, among which some 300 larger ensembles have already been identified by previous scholars, starting with the monumental publication of Pleyte and Ros$\mathrm{si}^{20}$ during the second part of the nineteenth century - and a qualitative point of view, since the material includes a significant amount of fragmentary objects. Many of these papyri are documents of paramount historical importance: from administrative reports to judicial cases (e.g., necropolis and temple administration, judicial texts) and from literary compositions to religious, magical and ritual texts, almost every domain of social life and knowledge of ancient Egypt is covered by the Turin collection.
Some of the manuscripts are more or less complete, but numerous tiny hieratic fragments kept in folders belong either to these ensembles or to other unidentified texts. This material has been part of the museum collection for almost two centuries and is of significant historical importance, but has remained largely unpublished.

Since 2015, Egyptologists working on Ramesside hieratic manuscripts - Günter Burkard (Munich), Rob J. Demarée (Leiden), Andreas Dorn (Uppsala), Kathrin Gabler (Basel), Maren Goecke-Bauer (Munich), Fredrik Hagen (Copenhagen), Ben Haring (Leiden), Stéphane Polis (Liège), Lutz Popko (Leipzig) and Daniel Soliman (Leiden), with the full support of the Museo Egizio - have laid the necessary groundwork in order to make this collection available to a wider audience, which includes a first index of the papyrus fragments, the creation and structuring of digital data about papyrus manuscripts, pilot studies in palaeography and automatic handwriting analysis, as well as a study of literary fragments. This supported the development of the Turin Papyrus Online Platform (TPOP), ${ }^{21}$ which is managed and supervised by Susanne Töpfer (Turin) since 2017 and is now available online: https://collezionepapiri.museoegizio.it/. This platform facilitates the work on the Turin papyri, from the initial recording of fragments and their annotation with metadata to their online publication. It is one of the two digital cornerstones of the "Crossing Boundaries" project (see further under $\$ 2.4 .2$.).

\section{3. "Heterogeneous" papyri: Definition and examples}

As stated above, the study object of the "Crossing Boundaries" project is the group of so-called "heterogeneous" papyri. This new label refers to a category of papyri combining texts and drawings of different types in a single manuscript. One can find, for example, a papyrus containing a copy of a letter to the authorities, a note about a judicial case, a hymn to a pharaoh, and a drawing to be copied on a coffin. Heterogeneous papyri should be carefully distinguished from another category, which is much better studied in Egyptological literature, the so-called miscellanies. ${ }^{22}$ Both miscellanies and heterogeneous papyri contain texts of different genres, but miscel- 

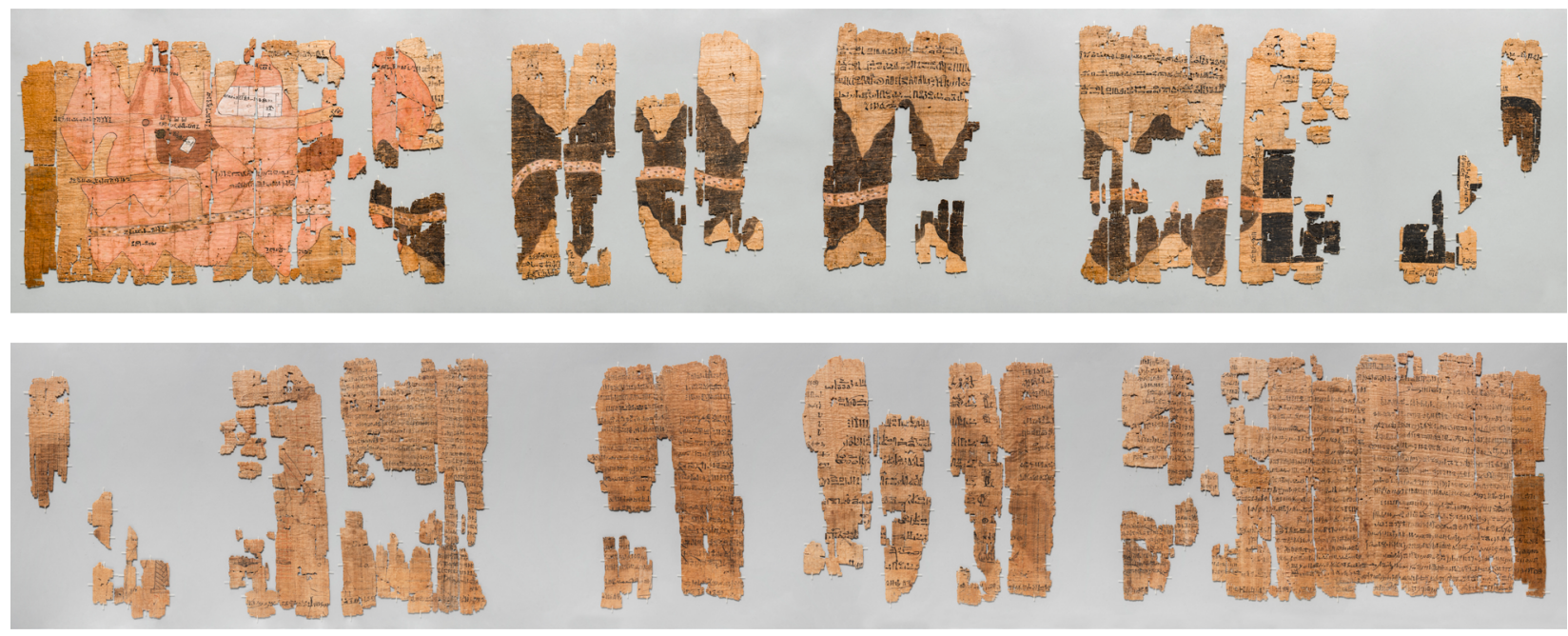

Fig. 1: The Turin Papyrus Map, recto and verso (P. Turin Cat. 1879 + Cat.1969 + Cat.1899 + Cat. 2083/182 + Cat. 2082/174). Photo by Federico Taverni/Museo Egizio.

lanies are creative compendia produced by individual scribes and framed as epistolary teachings. As such, they are basically synchronic compositions in which the scribe exhibits his know-how and masterful hieratic hand (and they can obviously be part of heterogeneous documents, as illustrated by P. Turin $A$ and P. Turin B).

Heterogeneous papyri, on the other hand, are the result of the actual activities of one or several scribes, who made use of papyri in their daily life, sometimes opportunistically. These papyri usually have a long history of use that can span over decades, and each of the textual or representational units can be envisioned as a different witness, having its own distinctive features (text type, handwriting, content, layout, etc.), even if the texts regularly display thematic relationships.

For the sake of clarity, we will succinctly illustrate the category of heterogeneous papyri with two examples from Turin. Let us first consider the famous Turin Papyrus Map, also known as the Goldmine Papyrus (Fig. 1, P. Turin Cat. $1879+$ Cat.1969 + Cat.1899 + Cat.2083/182 + Cat.2082/174 [https:// papyri.museoegizio.it/!10]). On the recto of this document we find the oldest topographical and geological map in history (c. 1150 BCE), representing a region of the Wadi Hammamat (in the Eastern Egyptian desert) where the Egyptians quarried blocks of greywacke (the famous bekhen-stone) and extracted gold. ${ }^{23}$ However, while the map attracted the greater scholarly attention, ${ }^{24}$ the verso of the document is equally rich and has not been properly published or studied so far, apart from the first two columns. ${ }^{25}$ Based on different criteria (prosopography, palaeography, and micro-history), Harrell and Brown ${ }^{26}$ suggested that the map and several texts on the verso might have been drawn and written by the scribe Amennakhte (v). ${ }^{27}$ Recently, parallels on ostraca from Deir el-Medina ${ }^{28}$ - where the name of this scribe occurs -, as well as the certain reading of his name and filiation in a lacunal context at the end of the great hymn of Fragment H-I-J, ${ }^{29}$ have confirmed this hypothesis: Amennakhte (v) - perhaps with his colleague, the scribe Hori ${ }^{30}$ - used this papyrus over a period of at least 15 years for writing such diverse texts as hymns to the king, religious compositions, administrative accounts, copies of letters to the king and authorities, as well as drawings of gods and animals. The precise chronology and purposes of these texts have yet to be established, but there is no doubt that a detailed examination of this heterogeneous papyrus will enhance understanding of the scribal habits in the community of Deir el-Medina during the mid-Twentieth Dynasty.

Another interesting example of a heterogeneous papyrus is P. Geneva MAH 15274 + Turin CGT 54063 [https://papyri.museoegizio.it/!299]. ${ }^{31}$ This document, nowadays split between Italian and Swiss locations, bears seven columns of magical spells on its recto and ends with a record about the chief of police Montumose (I). On its verso, one or more scribes wrote six columns about administrative matters in 


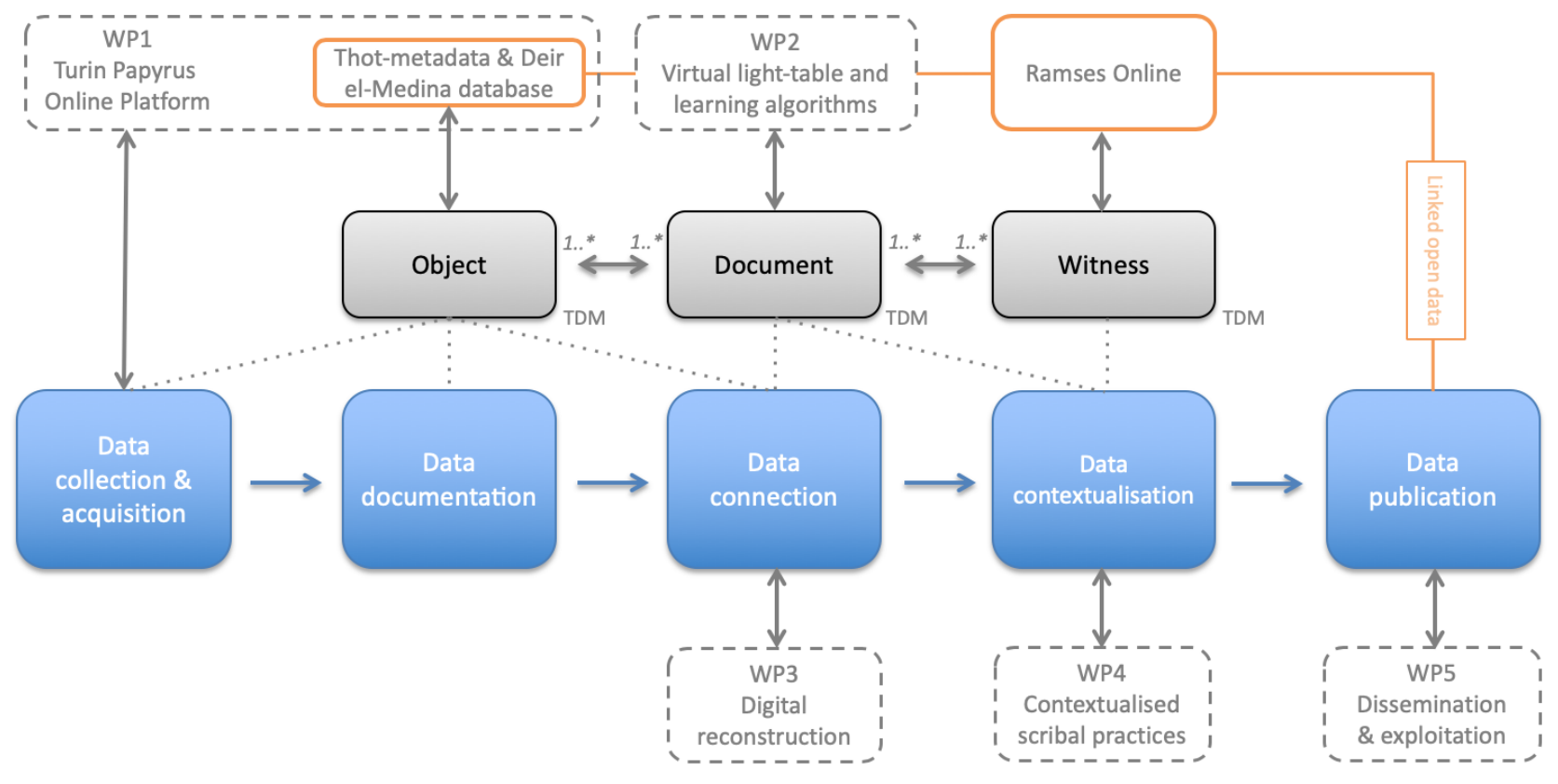

Fig. 2: The workflow and work packages of the "Crossing Boundaries" project.

various years of the Twentieth Dynasty: regarding the transfer of copper tools in year 6 of Ramesses VI (chisels were needed on a regular basis for the construction of the royal tombs); about the arrival of different scribes in year 3 (probably of the same king); and concerning judicial disputes and the delivery of goods. In the last column, one finds more magical spells (against scorpion stings). The detailed chronology of these texts has also to be established, but this case shows how very different topics could find their way onto a single document over time. Interestingly enough, some spells of this papyrus are almost identical with the ones in P. Chester Beatty $\mathrm{V}$ and P. Leiden I $349 \mathrm{I}$, and indeed it can be argued that this heterogeneous document once belonged to the so-called Chester Beatty archive, ${ }^{32}$ first owned by the famous scribe Qenhirkhopshef (i) ${ }^{33}$ during the Nineteenth Dynasty, and subsequently enriched and reused by generations of scribes of his family over dozens of years.

\subsection{Research plan}

The project's workflow can be described as encompassing five logical steps: (1) data collection and acquisition, (2) data documentation, (3) data connection, (4) data contextualisation, (5) data publication (Fig. 2, blue). For the sake of clarity, the central steps are mapped onto three conceptual elements of the Thot Data Model, ${ }^{34}$ namely the Object, the Docu- ment, and the Witness (Fig. 2, dark grey). This general structure allows us to define five work packages (Fig. 2, light grey) and to map already available electronic tools and resources (Fig. 2, orange).

\subsubsection{WP1: Restoration, digital acquisition and encoding of papyri in TPOP}

The goal of WP1 is to make available in a digital format all the fragments of papyri of the Museo Egizio that are relevant for the project and to document them systematically with metadata. WP1 is overseen by Susanne Töpfer (Turin) and facilitated by the Turin Papyrus Online Platform ${ }^{35}$ (TPOP, see $\S 2.2$.$) . Most of the larger papyri were already stored$ digitally in TPOP before the project began in 2019, but thousands of smaller fragments were still kept in cardboard folders. Since these smaller pieces are of paramount importance for the subsequent reconstruction of documents, WP1 includes: (1) the identification of the relevant (fragments of) papyri; (2) their consolidation and restoration by a professional restorer; (3) the digitisation and encoding of these objects in TPOP, with metadata about their current location (including catalogue numbers), physical features (including measurements and description of the material aspects), the features of the scripts (layout, state of conservation, type of script, keywords, date, etc.), and drawings (type, colour, grid, etc.) found on their surface, as well as a full descrip- 
tion of the text content (keywords, hieroglyphic transcription, transliteration, translations, etc.).

\subsubsection{WP2: Virtual light table and learning algorithms}

The aim of WP2 is to use state-of-the-art technology and machine learning research in order to develop new IT solutions for assisting and transforming traditional Egyptological tasks. On the one hand, it targets the implementation of a digital light table that will allow scholars to piece together remotely digital images of fragments of papyri, just as if they were working on the originals (see §3.2.3.). On the other hand, it aims to develop learning algorithms that will classify fragments and suggest possible matches between them based on an analysis of the images and related metadata. ${ }^{36}$ WP2 is managed by Stephan Unter (Basel) within the framework of his PhD dissertation in computer sciences.

The TPOP is fully functional for recording information about papyri, but to exploit its full potential it needs to be extended with a virtual light table (VLT), a tool allowing the collaborative digital reconstruction of documents. The data model and technical requirements for this extension have been defined, but it still needs to be implemented and designed in an ergonomic fashion. The digital reconstruction of the papyri will be further facilitated by the development of dedicated algorithms using (a) objective features inferred from the digital images (such as the pattern of the fibres of the papyrus, its colour, automatic detection of text layout, features of handwritings, etc.), and (b) manually entered metadata to be extracted from the TPOP. To put it simply, the platform will present the researchers with papyrus fragments sharing similar features and facilitate comparisons between hundreds of pieces. The combination of the virtual light table with the learning algorithms should result in a highly innovative and unparalleled tool for studying fragmentary collections, ${ }^{37}$ which will be made available as open source by the end of the project.

\subsubsection{WP3: Digital reconstruction of heterogeneous papyri}

Digital reconstruction of heterogeneous documents in WP3 is the Egyptological side of WP2, which pro- vides the required technical environment. Besides pursuing their own individual research interests within the project, all Egyptologists on the project collaborate on this central work package. Nowadays, it is estimated that approximately $25 \%$ of the Turin hieratic papyri are heterogeneous. Key elements for their reconstruction are "mixed fragments", i.e., individual pieces of papyrus displaying different texts and hands (or both texts and drawings) that might point to different scribes, textual genres, and uses (see below, §3.2.2). Fig. 3 is such a fragment. On the recto are five lines of a punctuated text - belonging to the "miscellanies" genre -, while the verso preserves bits of two lines of an unidentified text. Note that the signs on the verso (and the interlinear space) are more than twice as big as the ones on the recto, and that the ductus is markedly different. As such, CP122/020 qualifies as a mixed fragment and two distinct witnesses can be posited for the recto and the verso.

Such fragments are the pieces of a puzzle, the final aim being to connect and/or join clusters of apparently disconnected fragments. A direct result of this WP will be the online publication of reconstructed documents.

\subsubsection{WP4: Contextualising complex scribal practices}

Switching from the reconstruction of documents to their detailed analysis, WP4 focuses on two complementary dimensions: the individual level of the scribes (studying the different hands on heterogeneous manuscripts and the related prosopographical information) and the diachronic use of these papyri (situating these sources within the broader context of archive keeping in Deir el-Medina).

The starting point for our study of the first dimension, that of individual scribes, will be letters. This text type will be studied by Kathrin Gabler (Basel) in the framework of her post-doctoral project. Letters from the Ramesside period contain a wealth of prosopographical information about their senders and recipients and, because they are used in a variety of contexts - from informal letters about daily businesses to models or copies of letters addressed to the authorities or the king - a great variety of hands can be distinguished. This allows us to for- 


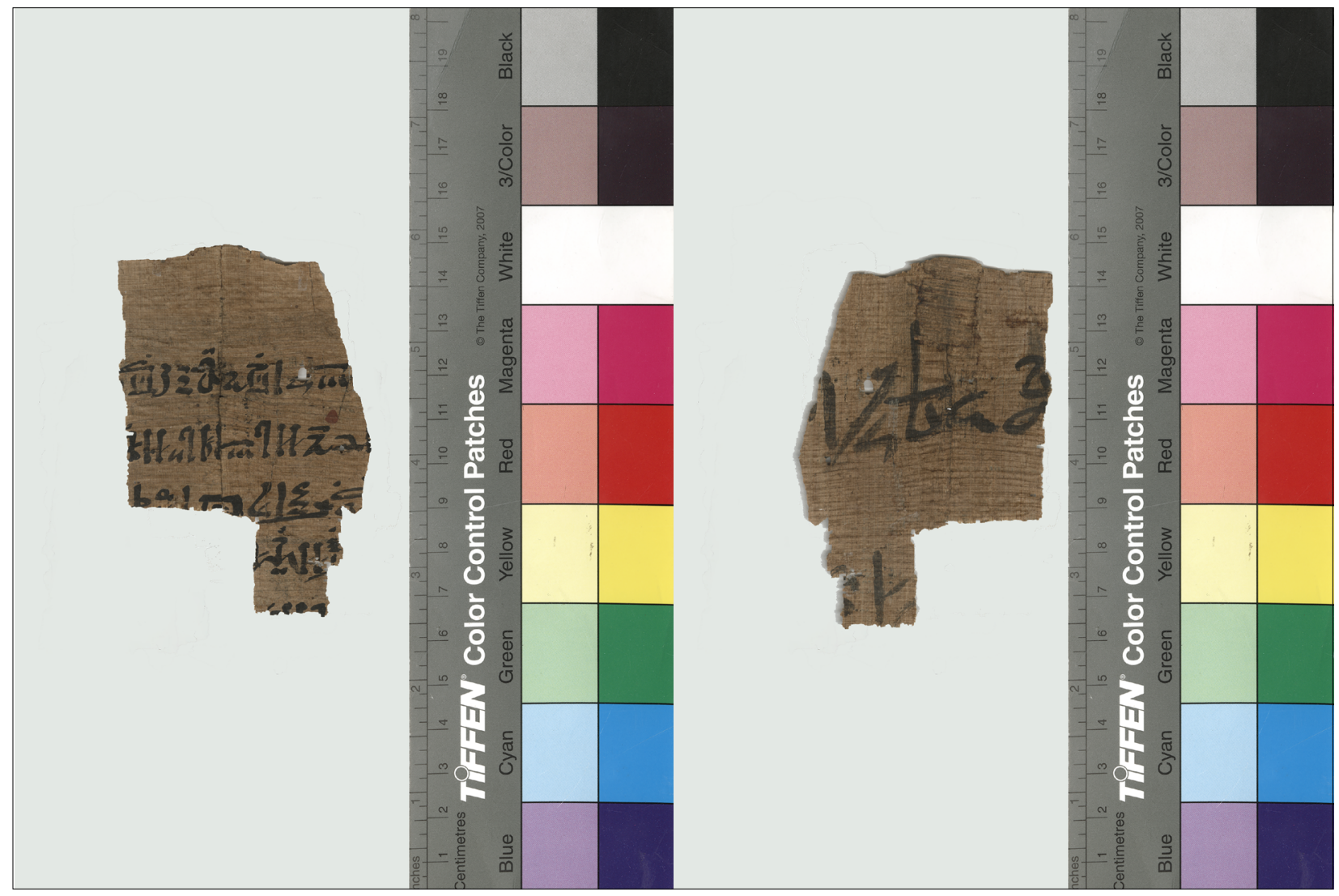

Fig. 3: An example of a "heterogeneous fragment": CP122/020 recto and verso. Scans by Museo Egizio.

mulate hypotheses about the paleographic repertoire of scribes and to attribute hands to individual scribes. As a second step, other text categories will be investigated: since we know that the same scribes produced other types of administrative and judicial texts and composed (or copied) literary, magical and religious works, a major challenge will be to identify regularities in terms of ductus, layout and variations in sign-shapes that can be interpreted as "markers" for certain scribes, and to track these regularities across texts and documents. ${ }^{38}$

The second dimension to be studied will be the internal diachrony of the heterogeneous papyri, trying to unveil use patterns accounting for the layout and textual organisation of these documents. Preliminary studies ${ }^{39}$ suggest that, even when papyri are used over a long period of time, thematic and social factors may explain the (seemingly random, or at least complex) distribution of texts and drawings. An expected outcome of this study is to be able to situate the heterogeneous papyri of Turin within the broader context of scribal practices at Deir el-Medina, envisioning the recording of information on papyrus as a deeply embedded social process. ${ }^{40}$ Do texts relative to work administration also appear on heterogeneous papyri, or is this practice limited to other text types, of a more private character ${ }^{41}$ Are we dealing with official "archives" of the necropolis administration or with private libraries, ${ }^{42}$ and does this distinction make any sense at all in the context of Deir el-Medina? ${ }^{43}$ Can we reconstruct coherent ensembles and historical scenarios elucidating the transmission of these papyri over decades in the Theban necropolis? Should we postulate the coexistence of several ancient archives in Turin, or is a single provenance more likely? These questions will be at the center of Renaud Pietri's three-year post-doctoral position at the University of Liège.

\subsubsection{WP5: Dissemination}

The results of the project will be disseminated in traditional publication types such as books and papers. ${ }^{44}$ Additionally, hundreds of fragments of papyrus will be encoded within the TPOP and published online as linked open data (with pictures, complete description, as well as a hieroglyphic transcription and a transliteration). The online material is connected to resources such as the Thesauri and On- 
tology for Documenting Ancient Egyptian Resources (http://thot.philo.ulg.ac.be), the Deir el-Medina Database (https://dmd.wepwawet.nl), and the hieroglyphic corpus Ramses Online (http://ramses.ulg. ac.be). The Data and Service Center for the Humanities (DaSCH; http://dasch.swiss), in collaboration with the Egyptologists at the University of Basel, will ensure the long-term preservation and maintenance of these research data.

Our website (http://crossing-boundaries.uliege.be) will advertise the results and link the technical (learning algorithm), papyrological (virtual light table), and Egyptological components of the project. The IT solutions developed for the "Crossing Boundaries" project will be made available online as open source solutions. We anticipate that other institutions with fragmentary collections of written sources would benefit from a virtual light table and efficient algorithms facilitating the digital reconstruction of ancient documents.

\section{Progress report - 2019}

The project "Crossing Boundaries" officially began on 1 March 2019. In this section, we introduce the team and general organisation of the project (\$3.1.), present ongoing work and research questions that have been tackled during the first year of the project (§3.2.), and summarise dissemination activities carried out in 2019 (\$3.3.).

\subsection{Team and internal meetings}

The recruitment procedure was conducted over the course of 2019. The main team consists of seven scholars working under the supervision of three principal investigators: Christian Greco (Turin), Antonio Loprieno (Basel), and Stéphane Polis (Liège). At the Museo Egizio, Susanne Töpfer organises the documentation, digitisation and encoding of the papyri in TPOP, which is carried out once the fragments have been consolidated and restored by an external restorer financed by the project. The Basel team consists of two post-doctoral researchers (Kathrin Gabler and Matthias Müller), two PhD candidates (Egyptologist Elena Hertel and Egyptologist/ computer scientist Stephan Unter), and two student assistants (Evelyne Marty and Klaudija Stanic). In Liège, the team consists of two post-doctoral posi- tions (Nathalie Sojic and Renaud Pietri), and three student assistants (Marie Dransart, Daphné Nuyts, and Philipp Seyr). In addition to the project members, several collaborators of the Museo Egizio are working on papyrological material related to the project: Micòl Di Teodoro (post-doctoral researcher), Andrea Fanciulli ( $\mathrm{PhD}$ candidate), and Martina Landrino (PhD candidate). Finally, Serge Rosmorduc (Paris) collaborates with the project for the IT aspects involving hieroglyphic transcriptions and transliteration. A description of the individual curricula and projects can be found in the dedicated section of the project website (http://web.philo.ulg. ac.be/x-bound/members/) and the website of the Turin Papyrus Collection (https://collezionepapiri. museoegizio.it/en-GB/section/Papyrus-Collection/ Our-projects/Research-projects/).

\subsection{Ongoing work}

During the first year of the project, the team members have focused on three central tasks: the restoration, digitisation, and recording of fragments of papyrus in TPOP (\$3.2.1.), the hieroglyphic transcription and identification of contents of the said papyri (§3.2.2.), and the design and initial implementation of a virtual light table (§3.2.3.).

\subsubsection{Fragments: restoration and recording}

The fragments are currently stored in cardboard folders that are numbered consecutively as CP1, $\mathrm{CP} 2$, etc. ( $\mathrm{CP}=$ "Cartelline Papiri"). While processing the material, $\mathrm{CP}$ numbers are used as inventory numbers for the fragments that they contain: the undocumented fragments do not receive new inventory numbers, but sub-numbers based on the CP-numbers, e.g., CP058/001 or CP058/012. This allows the curatorial staff to keep track of the folder they originally come from. Before removing the fragments from a folder, the original situation is photographically documented.

The vast majority of papyrus fragments need to be cleaned, unfolded, straightened, and anchored with correctly aligned fibres in order to improve (or simply allow) legibility, and to produce pictures of high quality that can be worked on in TPOP. The papyrus fragments are being carefully conserved and consol- 

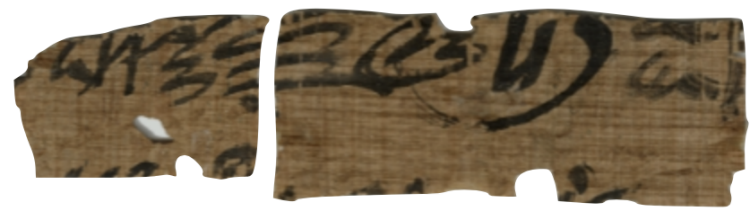

Fig. 4: Join between CP168/013 (right) and CP168/015 (left). Scans by Museo Egizio.

idated by Livio Nappo in accordance with the preventive strategies outlined in the Advanced Papyrological Information System Guidelines for Conservation of Papyrus. ${ }^{45}$ Their ancient appearance is conserved, using reversible methods. The front and back (recto and verso) of each papyrus fragment are scanned at a 1:1 scale along with a colour separation guide. The pictures meet the standards required for subsequent processing in the TPOP (400 dpi, TIFF) and for the VLT (1200 dpi, TIFF). Following their consolidation, the fragments are mounted between $2 \mathrm{~mm}$-thick glass plates labelled with the CP sub-number. To date, approximately 304 entries of larger Ramesside manuscripts with inventory numbers have been recorded in the TPOP, along with more than 1200 out of 1500 restored $\mathrm{CP}$ fragments. The number of consolidated, restored and documented fragments is constantly growing. They will be visible at first only to project members and collaborators, but will be openly accessible online in TPOP from 2023 onward.

\subsubsection{Identification of contents and hieroglyphic transcriptions}

Thanks to the online availability of fragments from the $\mathrm{CP}$ folders, the identification of the content and the hieroglyphic transcription of the hieratic texts began in April 2019. For pragmatic reasons, we divided the material according to the nature of the texts: Kathrin Gabler and Matthias Müller (Basel) are dealing with the administrative texts, Renaud Pietri, Stéphane Polis, and Nathalie Sojic (Liège) with the literary, magical and religious texts. After entries for individual fragments have been created in the TPOP, data about the witnesses (keywords, transcription, date, philological comments, etc.) and their materiality (handwriting, ink, etc.) are added. So far, more than a thousand fragments have been thus processed. This preliminary work has revealed joins between individual fragments (e.g., Fig. 4), but also looser connections between smaller fragments and larger fragmentary papyri (e.g., Fig. 5).

The fragments shown in Fig. 5 belong to a document recording fish deliveries. P. Turin Cat. 1933 (far right) and Provv. 6259 (to its left) are preserved for the complete height of the papyrus. However, the distribution of the text and the pattern of the fibres indicate that they stem from different columns. The $\mathrm{CP}$ fragments from two different folders (left part of the image) are the remains of at least two additional columns, as shown by the distribution of texts on the other side

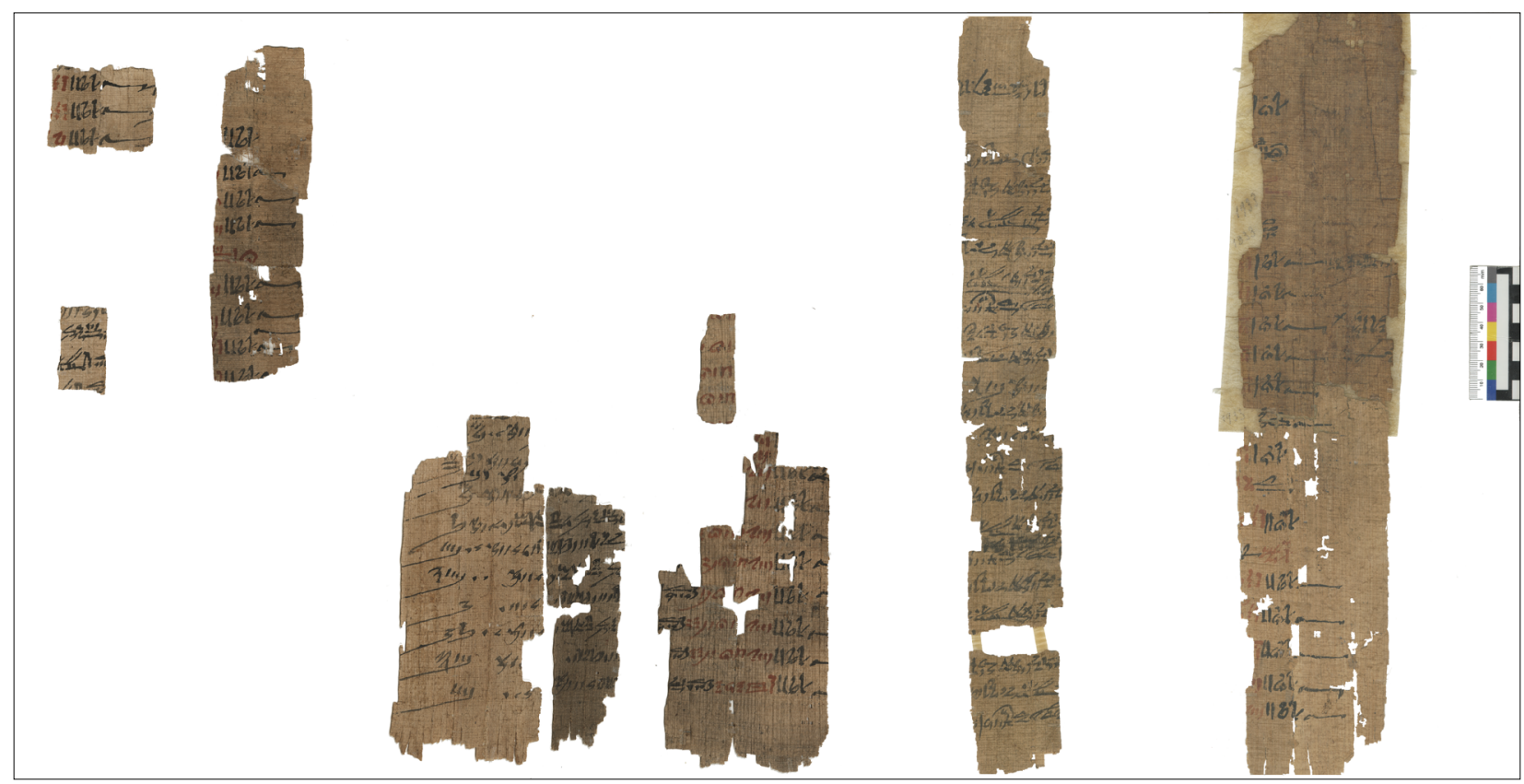

Fig. 5: A record of fish deliveries. P. Turin Cat. 1933 + Provv. 6259 + CP041, and CP057 (verso). Scans by Museo Egizio. 


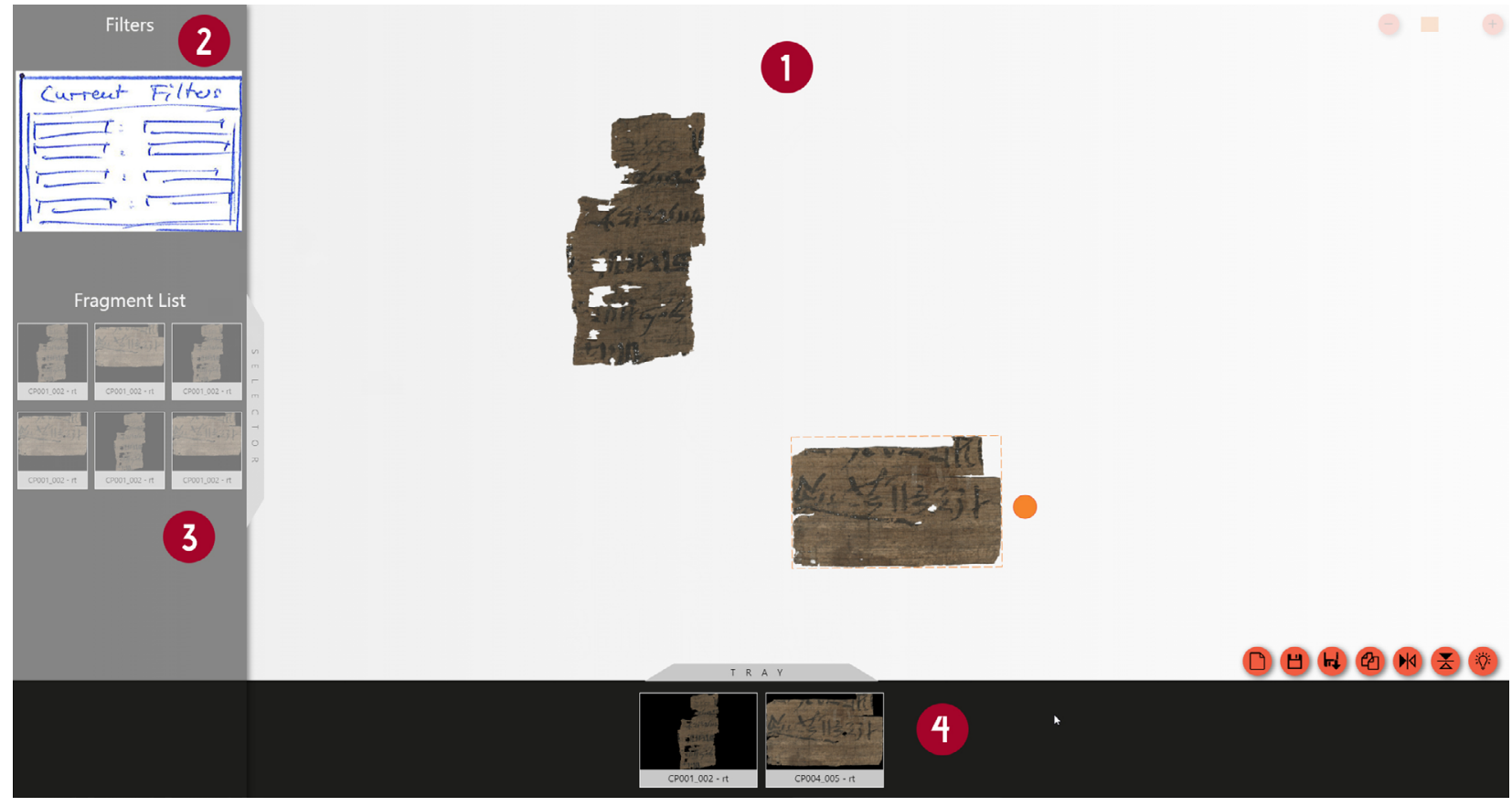

Fig. 6: Screenshot/concept drawing of the Virtual Light Table: (1) light table with fragments; (2) section to filter fragments; (3) list of fragments; (4) tray area showing loaded elements. Scans by Museo Egizio.

of the papyrus as well as the sequence of dates. Based on the fact that P. Turin Cat. 1933 shows traces of line endings at its right edge, we may reconstruct at least five columns of text. Furthermore, on the basis of the names of the fishermen and the change from a regnal year 1 to a year 2 in the first month of Akhet (on P. Turin Cat. 1933), we can assign this document to the reign of Ramesses IX. This example illustrates nicely the potentialities of the Turin collection in terms of reconstruction of larger documents.

Besides working on fragments, the post-doctoral scholars are also encoding data about larger papyri, partly drawing on existing resources such the Ramses Online corpus (http://ramses.ulg.ac.be/) and Kathrin Gabler's personal database, in order to add to the corpus of texts that could be used to train the learning algorithms (\$3.2.3.).

\subsubsection{The virtual light table and the learning algorithms}

Over the past months, some first steps towards the implementation of the virtual light table (VLT) were made. The VLT is being designed around a server-client architecture, using the open-source framework Electron. ${ }^{46}$ It provides all the packages needed to run the application in different operating systems, such as Windows or Linux. The user can load exist- ing reconstructions or browse, filter, and select fragments from the TPOP database (or other uploaded data sources), and add them to the canvas (making sure that the loaded images are at the same scale). The user can then move, rotate, and flip the objects to reconstruct larger documents. Finally, the results can be saved and distributed to other scholars, or exported for publication. The intermediate status of the user interface can be seen in Fig. 6 .

Automatic classification and matching of fragments, relying on modern machine-learning techniques (cf. WP2 in §2.4.2.), will eventually be implemented in the VLT framework. In this particular field of computer science, algorithms often try to learn from annotated structured data in order to infer classification rules and patterns. Subsequently, they make predictions about new, yet unseen data based on the rules they have learned before. The classification and reconstruction of papyri is a complex and challenging task in multiple ways: the material is very fragmented; the papyrus has a texture of its own, which interferes with its decoration and writing; the handwriting is often challenging to read; the script includes a high number of individual signs; etc. One of the most challenging issues is possibly the relative smallness of the set of training data, since machine learning processes usually process thousands of training images. 


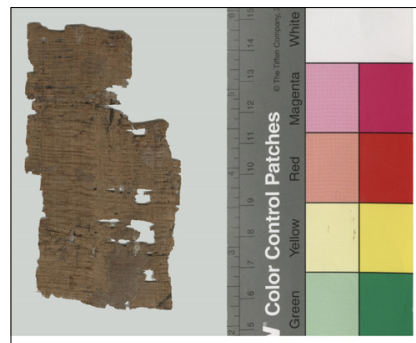

Original Image

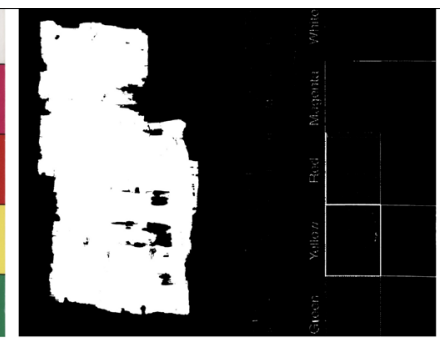

Binary Mask

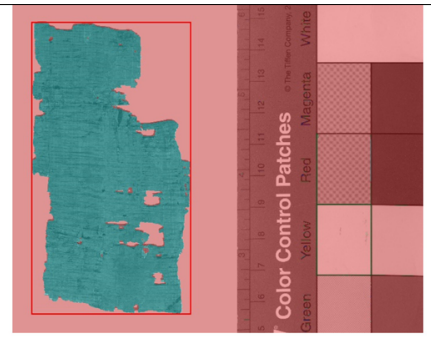

Detected Papyrus

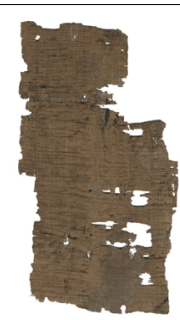

Segmented Result

Fig. 7: Segmentation steps, from left to right: (1) uploaded RGB image; (2) binary mask (white for papyrus, black for background); (3) localisation and creation of minimal bounding box; (4) segmented result where all the background pixels are transparent. Scan by Museo Egizio.

The very first step in the process is the segmentation of papyrus images, i.e., separating the fragments from the background and other objects within the image. In image segmentation - a special case of object detection - a classifier calculates object-class probabilities not just for whole images, but for each pixel within an image. These probabilities indicate to which class a pixel belongs - e.g., papyrus or background. The result is a binary mask (white: papyrus; black: background) which can be used to create an accurate cutout of the papyrus fragment. Fig. 7 shows the original image, the binary mask, and the cutout, obtained using an artificial neural network with a Unet architecture originally developed to segment cells in biomedical images. ${ }^{47}$ These results will be further improved and serve as a basis for the next steps in analysing and classifying fragments.

\subsection{Dissemination}

In order to ensure the visibility of the project, we set up a web page for the project (http://crossing-boundaries.uliege.be). ${ }^{48}$ In addition to basic information on the project (team, background, research questions, sub-projects), this website summarises past, current and planned activities ${ }^{49}$ (presentations of the project, lectures, publications, and meetings), and the "News" page provides information about current developments (e.g., job opportunities, new

Notes

${ }^{1}$ The project is co-funded by the Swiss National Science Foundation and the Belgian Fund for Scientific Research, and is supported financially by the Museo Egizio (Turin).

${ }^{2}$ On the material from Deir el-Medina in the Turin collection, see recently Del Vesco and Poole, in Dorn tools, etc.). During 2019, we presented "Crossing Boundaries" at several international venues and the first results were discussed in three workshops (details available on the web page).

\section{Impact}

The project "Crossing Boundaries" is expected to have an impact on three main levels. First, from a cultural heritage point of view, it will lead to the restoration and reconstruction of a sizable quantity of ancient Egyptian papyri from fragments held in the Turin collection. These papyri will be available online for study by the end of the project, a significant step towards open access to ancient Egyptian data. Second, from the point of view of digital humanities, a dedicated interface coupled with learning algorithms (the VLT) will be developed to piece together hundreds of fragments of papyri. This solution could be applied to many other similar collections and will be distributed under an open-source license. Finally, from an Egyptological perspective, significant new insights into Egyptian scribal culture will be gained through the project, showing how writing in ancient Egypt was a deeply social and contextualised practice where mixed categories of knowledge (administrative, legal, historical, religious, or literary) could be instantiated in a single document and mastered by individual scribes.

and Polis (eds.), Outside the Box, 2018.

${ }^{3}$ Černý, The Valley of the Kings, 1973; Černý, A

Community of Workmen, 2001²; Valbelle, "Les ouvriers de la tombe”, 1985; Davies, Life Within the Five Walls, 2018.

${ }^{4}$ Polis, in Cromwell and Grossman (eds.), Scribal Repertoires, 2017; Haring, in Hoogendijk and van 
Gompel (eds.), The Materiality of Texts, 2018.

${ }^{5}$ Janssen, in Demarée and Egberts (eds.), Village Voices, 1992.

${ }^{6}$ Demarée, in Pantalacci (ed.), La lettre d'archive, 2008; Haring, forthcoming.

${ }^{7}$ Cf. Černý, Catalogue des ostraca hiératiques, 1935, p. III-IV.

${ }^{8}$ See, however, Mathieu's contextualised approach to the literary sources of Deir el-Medina, in Andreu (ed.), Deir el-Médineh et la Vallée des Rois, 2003, and Gaber et al., À l'oeuvre on connaît l'artisan (2017).

${ }^{9}$ Ragazzoli, ZÄS 137 (2010). With specific regard to Deir el-Medina, see Loprieno, in Dorn and Hofmann (eds.), Living and Writing in Deir el-Medine, 2006.

${ }^{10}$ See recently Ragazzoli, Scribes, 2019.

${ }^{11}$ Donker van Heel and Haring, Writing in a Workmen's Village, 2003; Gabler, in Haring et al. (eds.), Proceedings of the Conference "Decoding Signs of Identity", 2018; Gabler, Who's Who Around Deir el-Medina, 2018.

${ }^{12}$ Polis, in Cromwell and Grossman (eds.), Scribal Repertoires in Egypt, 2017.

${ }^{13}$ E.g., Bickel and Mathieu, BIFAO 93 (1993).

${ }^{14}$ E.g., Dorn, Arbeiterhütten im Tal der Könige, 2011.

${ }^{15}$ Notably Parkinson, Reading Ancient Egyptian Poetry, 2009; Parkinson, in Moers et al. (eds.), Dating Egyptian Literary Texts, 2013.

${ }^{16}$ Piquette and Whitehouse, Writing as Material Practice, 2013.

${ }^{17}$ It is noteworthy, in this regard, that new fragments of the so-called "Stato civile" - a dossier attested only in the Turin material so far (Demarée and Valbelle, Les registres de recensement) - have been identified among the papyri coming from Deir el-Medina kept by the French Archaeological Institute in Cairo; see Demarée, Dorn, and Polis, BIFAO 120 (2020).

${ }^{18}$ Hagen and Soliman, in Bausi et al. (eds.), Manuscripts and Archives, 2018.

${ }^{19}$ See especially the reports by Roccati (OrAnt 14 [1975]; Magica Taurinensia, 2011) and Demichelis (in Ciampini and Demichelis [eds.], Dal Po al Nilo, 2016).

${ }^{20}$ Pleyte and Rossi, Papyrus de Turin, 1869-1876.

${ }^{21}$ Cf. Töpfer, Rivista del Museo Egizio 2 (2018), https:// rivista.museoegizio.it/article/the-turin-papyrusonline-platform-tpop-an-introduction/.

${ }^{22}$ Gardiner, Late-Egyptian Miscellanies, 1937; Hagen, in Dann (ed.), Current Research in Egyptology, 2006; Goelet Jr., in D’Auria (ed.), Servant of Mut, 2008; Ragazzoli, in Morlet (ed.), Lire en extraits, 2015; and Ragazzoli, in Gillen (ed.), (Re)productive Traditions in Ancient Egypt, 2017; Ragazzoli, Scribes, 2019.

${ }^{23}$ Demarée, in Favry et al. (eds.), Du Sinaï au Soudan, 2017.

${ }^{24}$ See for instance Goyon, ASAE 49 (1949); Baud, BIFAO 90 (1990); Harrell and Brown, JARCE 29 (1992).

${ }^{25}$ Janssen, JARCE 31 (1994); Hovestreydt, LingAeg 5 (1997).

${ }^{26}$ Harrell and Brown, JARCE 29 (1992), pp. 101-04.

${ }^{27}$ For an overview about this individual, see Dorn and Polis (2018).

${ }^{28}$ O. IFAO OL 4039 (see Dorn and Polis, BIFAO 116 [2016], pp. 74-81) and O. IFAO OL 3171+3162 (see Claude and Frère, in Albert and Gasse, Études de documents hiératiques, in prep.).
${ }^{29}$ Dorn and Polis, The Turin Papyrus Map (in prep.).

${ }^{30}$ This problematic point will be discussed in Dorn and Polis, The Turin Papyrus Map (in prep.).

${ }^{31}$ Massart, MDAIK 15 (1957); Roccati, BSEG 7 (1982).

${ }^{32}$ Pestman, in Demarée and Janssen (eds.), Gleanings from Deir el-Medîna, 1982.

${ }^{33}$ Davies, Who's Who at Deir el-Medina, 1999, pp. 84-86; Donker van Heel and Haring, Writing in a Workmen's Village, 2003, pp. 41-48; Štubňová, “The Scribe of the Tomb Kenherkhepeshef”, 2013; Štubňová, GM 248 (2016).

${ }^{34}$ Polis and Razanajao, BICS 59:2 (2016).

${ }^{35}$ Cf. Töpfer, Rivista del Museo Egizio 2 (2018), https:// rivista.museoegizio.it/article/the-turin-papyrusonline-platform-tpop-an-introduction/.

${ }^{36}$ For a similar approach to a collection of Demotic papyri, see the GESHAEM project (The Graeco-Egyptian State - Hellenistic Archives from Egyptian Mummies) coordinated by Marie-Pierre Chaufray (https:// geshaem.huma-num.fr), which developed a Siamese neural network architecture, called Papy-S-Net, to match papyrus fragments (Pirrone, Beurton Aimar, and Journet, in HIP 19 [2019], pp. 73-83). Unter, in Verbovsek et al. (eds.), BAJA 10 (in prep.).

${ }^{37}$ Reggiani, Digital Papyrology I, 2017.

${ }^{38}$ For a methodological points of view, see Janssen, JEA 73 (1987); Sweeney, JEA 84 (1998); van den Berg and Donker van Heel, in Demarée and Egberts (eds.), Deir el-Medina in the Third Millennium, 2000; McClain, in Dorn and Polis (eds.), Outside the Box, 2018.

${ }^{39}$ E.g., Dorn and Polis, The Turin Papyrus Map (in prep.).

${ }^{40}$ Eyre, The Use of Documents, 2013.

${ }^{41}$ Eyre, in Piacentini and Orsenigo (eds.), Egyptian Archives, 2009.

${ }^{42}$ Pestman, in Demarée and Janssen (eds.), Gleanings from Deir el-Medîna, 1982.

${ }^{43}$ Hagen and Soliman, in Bausi et al. (eds.), Manuscripts and Archives, 2018.

${ }^{44}$ See recently Gabler and Müller, in Gabler et al. (eds.), Text-Bild-Objekte, 2020, pp. 117-50, as well as Unter, in Verbovsek et al. (eds.), Formen kultureller Dynamik, forthcoming.

${ }^{45}$ Lau-Lamb, Guidelines, 2010.

${ }^{46}$ This framework ships with a NodeJS distribution (used, e.g., for controlling data and accessing local storage) and a Chromium-based browser.

${ }^{47}$ Ronneberger et al., MICCAI (2015).

${ }^{48}$ This webpage was initially developed in Basel and is now hosted in Liège in order to benefit from a WordPress framework. The webpage of the papyrus collection in Turin (https://collezionepapiri. museoegizio.it) also provides updates about the project.

${ }^{49}$ Our posters are available on the webpage (under Activities $>$ Presentations).

\section{Bibliography}

Baud, M., “La représentation de l'espace en Égypte ancienne : cartographie d'un itinéraire d'expédition”, BIFAO 90 (1990), pp. 51-63.

van den Berg, H. and K. Donker van Heel, "A Scribe's Cache from the Valley of Queens? The Palaeography 
of Documents from Deir el-Medina: Some Remarks", in R.J. Demarée and A. Egberts (eds.), Deir el-Medina in the Third Millennium AD: A Tribute to Jac. J. Janssen, Leiden 2000, pp. 9-49.

Bickel, S. and B. Mathieu, "L'écrivain Amennakht et son Enseignement”, BIFAO 93 (1993), pp. 31-51.

Černý, J., Catalogue des ostraca hiératiques non littéraires de Deir el Médineh. [Tome I] (nos 1 à 113) (DFIFAO 3), Cairo 1935.

Černý, J., The Valley of the Kings. Fragments d'un manuscrit inachevé (BdE 71), Cairo 1973.

Černý, J., A Community of Workmen at Thebes in the Ramesside Period (BdE 50), Cairo $2001^{2}$.

Claude, M. and M. Frère, "Les ostraca IFAO OL 3171 $a-g$ + OL 3162a-b. Le « brouillon » d'une lettre au roi relative au don d'une statue royale par le scribe de la Tombe Amennakhte (v) et textes divers", in Fl. Albert and A. Gasse (eds.), Études de documents hiératiques inédits, Cairo in prep.

Davies, B. G., Who's Who at Deir el-Medina: A Prosopographic Study of the Royal Workmen's Community (EU 13), Leiden 1999.

Davies, B. G., Life Within the Five Walls: A Handbook to Deir el-Medina, Wallasey 2018.

Del Vesco, P. and F. Poole, "Deir el-Medina in the Egyptian Museum of Turin. An Overview, and the Way Forward", in: A. Dorn and S. Polis (eds.), Out of the Box. Selected Papers from the Conference "Deir el-Medina and the Theban Necropolis in Contact”, Liège, 27-29 October 2014, Liège (AegLeod 11), Liège 2018, pp. 97-130.

Demarée, R.J., "Letters and Archives from the New Kingdom Necropolis at Thebes", in: L. Pantalacci (ed.), $L a$ lettre d'archive: communication administrative et personnelle dans l'antiquité proche-orientale et égyptienne; actes du colloque de l'Université de Lyon 2, 9-10 juillet 2004, Cairo 2008, pp. 43-52.

Demarée, R.J., "New Information on the Mining Expedition to the Wadi Hammamat in Year 3 of Ramesses IV", in: N. Favry, C. Ragazzoli, C. Somaglino and P. Tallet (eds.), Du Sinaï au Soudan : itinéraires d'une Égyptologue. Mélanges offerts au Professeur Dominique Valbelle (Orient \& Méditerranée 23), Paris 2017, pp. 101-06.

Demarée, R.J., A. Dorn, and S. Polis, "Les listes de maisonnées de Deir el-Médineh ( Stato civile »). Nouveaux fragments de l'IFAO et localisation de l'archive d'une lignée de scribes”, BIFAO 120 (2020), in press.

Demarée, R.J. and D. Valbelle, Les registres de recensement du village de Deir el-Médineh (le «Stato civile »), Leuven 2011.

Demichelis, S., "Ricomporre frammenti. Lavori in corso tra i papiri del Museo Egizio di Torino”, in: E.M. Ciampini and S. Demichelis (eds.), Dal Po al Nilo: Studi di filologia ed epigrafia egizia, Torino 2016, pp. 3-44.

Donker van Heel, K. and B.J.J. Haring, Writing in a Workmen's Village: Scribal Practice in Ramesside Deir el-Medina (EU 16), Leiden 2003.

Dorn, A., Arbeiterhütten im Tal der Könige: Ein Beitrag zur altägyptischen Sozialgeschichte aufgrund von neuem Quellenmaterial aus der Mitte der 20. Dynastie (ca. 1150 v. Chr.) (AH 23), Basel 2011.

Dorn, A. and S. Polis, “Nouveaux textes littéraires du scribe Amennakhte (et autres ostraca relatifs au scribe de la Tombe)", BIFAO 116 (2016), pp. 57-96.

Dorn, A. and S. Polis, The Turin Papyrus Map (in prep.).

Eyre, C., "On the Inefficiency of Bureaucracy”, in:

P. Piacentini and C. Orsenigo (eds.), Egyptian Archives: Proceedings of the First Session of the International Congress "Egyptian Archives / Egyptological Archives", Milano, September 9-10, 2008, Milano 2009, pp. 15-30.

Eyre, C., The Use of Documents in Pharaonic Egypt (Oxford Studies in Ancient Documents), Oxford 2013.

Gabler, K., "Methods of Identification Among the Deir el-Medina Workmen and Their Service Personnel: The Use of Names, Titles, Patronyms and Identity Marks in Administrative Texts from Deir el-Medina", in: B.J.J. Haring, K.V.J. van der Moezel and D.M. Soliman (eds.), Proceedings of the Conference "Decoding Signs of Identity”, December 2013, Leiden (EU 32), Leiden and Leuven 2018, pp. 191-218.

Gabler, K., Who's Who Around Deir el-Medina. Untersuchungen zur Organisation, Prosopographie und Entwicklung des Versorgungspersonals für die Arbeitersiedlung und das Tal der Könige (EU 31), Leiden and Leuven 2018.

Gabler, K. and M. Müller, "A Vizier's (Maybe not so) New Pieces of Furniture in the Renaissance Era: The Drawings and the Texts of P. Turin Cat. 2034 in Context", in K. Gabler, R. Gautschy, L. Bohnenkämper, H. Jenni, C. Reymond, R. Zillhardt, A. Loprieno-Gnirs, and H.H. Münch (eds.), Text-Bild-Objekte im archäologischen Kontext. Festschrift für Susanne Bickel (LingAeg StudMon 22), Hamburg 2020, pp. 117-50.

Gardiner, A.H., Late-Egyptian Miscellanies (BAe 7), Brussels 1937.

Goelet Jr., O., "Writing Ramesside Hieratic: What the Late Egyptian Miscellanies Tell Us About Scribal Education", in: S.H. D'Auria (ed.), Servant of Mut: Studies in Honor of Richard A. Fazzini (PdÄ 28), Leiden and Boston 2008, pp. 102-10.

Goyon, G., "Le papyrus de Turin dit «des Mines d’Or» et le Wadi Hammamat”, ASAE 49 (1949), pp. 337-92.

Hagen, F., "Literature, Transmission, and the Late Egyptian Miscellanies", in: Dann, R.J. (ed.), Current Research in Egyptology 2004: Proceedings of the Fifth Annual Symposium Which Took Place at the University of Durham January 2004, Oxford 2006, pp. 84-99.

Hagen, F. and D. Soliman, "Archives in Ancient Egypt, 2500-1000 BCE”, in: A. Bausi, C. Brockmann, M. Friedrich and S. Kienitz (eds.), Manuscripts and Archives: Comparative Views on Record-Keeping (SMC 11), Berlin 2018, pp. 71-170.

Harrell, J.A. and V.M. Brown, "The Oldest Surviving Topographical Map from Ancient Egypt: Turin Papyri 1879, 1899 and 1969", JARCE 29 (1992), pp. 81-105.

Haring, B.J.J., "Material Matters: Documentary Papyri and Ostraca in Late Ramesside Letters", in: F.A.J. Hoogendijk and S. van Gompel (eds.), The Materiality of Texts from Ancient Egypt: New Approaches to the Study of Textual Material from the Early Pharaonic to the Late Antique Period, Leiden and Boston 2018, pp. 43-51. Haring, B.J.J., "Late Twentieth Dynasty Ostraca and the End of the Necropolis Workmen's Settlement at Deir el-Medina”, in: C. Greco, F. Poole, S. Töpfer and P. del Vesco (eds.), Proceedings of the Workshop “Deir el-Medi- 
na Through the Kaleidoskop”, forthcoming.

Hovestreydt, W., "A Letter to the King Relating to the

Foundation of a Statue (P. Turin 1879 vso.)", LingAeg 5 (1997), pp. 107-21.

Janssen, J.J., “On Style in Egyptian Handwriting”, JEA 73 (1987), pp. 161-67.

Janssen, J.J., "Literacy and Letters at Deir el-Medîna”, in: R.J. Demarée and A. Egberts (eds.), Village Voices: Proceedings of the Symposium "Texts from Deir el-Medîna and Their Interpretation”, Leiden, May 31-June 1, 1991, Leiden 1992, pp. 81-94.

Janssen, J.J., “An Exceptional Event at Deir el-Medina (P. Turin 1879 verso)", JARCE 31 (1994), pp. 91-97.

Lau-Lamb, L., Advanced Papyrological Information System Guidelines for Conservation of Papyrus, University of Michigan 2010, https://www.lib.umich.edu/files/ collections/papyrus/APISconservation_fig.pdf.

Loprieno, A., "Towards a Detailed Perspective on Deir el-Medina”, in: A. Dorn and T. Hofmann (eds.), Living and Writing in Deir el-Medine. Social-Historical Embodiment of Deir el-Medine Texts (AH 19), Basel 2006, pp. 165-70.

Mathieu, B., "La littérature égyptienne sous les Ramsès d'après les ostraca littéraires de Deir el-Médineh, in G. Andreu (ed.), Deir el-Médineh et la Vallée des Rois : la vie en Égypte au temps des pharaons du Nouvel Empire. Actes du colloque organisé par le Musée du Louvre, les 3 et 4 mai 2002, Paris 2003, pp. 117-37.

Mathieu, B., "L'influence des découvertes de Deir el-Medina sur notre connaissance de la littérature égyptienne”, in H. Gaber, L. Bazin Rizzo, and Fr. Servajean (eds.), À l'oeuvre on connaît l'artisan ... de Pharaon! Un siècle de recherches françaises à Deir el-Medina (1917-2017), Milano 2017, pp. 105-09.

Massart, A., “The Egyptian Geneva Papyrus MAH 15274”, MDAIK 15 (1957), pp. 172-85.

McClain, S.E., "Authorship and Attribution: Who Wrote the Twentieth Dynasty Journal of the Necropolis?", in A. Dorn and S. Polis (eds.), Outside the Box: Selected Papers from the Conference 'Deir el-Medina and the Theban Necropolis in Contact'. Liège, 27-29 October 2014, Liège 2018, pp. 333-64.

Parkinson, R.B., Reading Ancient Egyptian Poetry: Among Other Histories, Chichester, UK and Malden, MA 2009.

Parkinson, R.B., "Sailing Past Ellsinore: Interpreting the Materiality of Middle Kingdom Poetry", in: G. Moers, K. Widmaier, A. Giewekemeyer, A. Lümers and R. Ernst (eds.), Dating Egyptian Literary Texts (LingAeg SM 11), Hamburg 2013, pp. 123-37.

Pestman, P.W., "Who Were the Owners, in the 'Community of Workmen', of the Chester Beatty Papyri”, in: R.J. Demarée and J.J. Janssen (eds.), Gleanings from Deir el-Medîna (EU 1), Leiden 1982, pp. 155-72.

Piquette, K. and R.D. Whitehouse, Writing as Material Practice: Substance, Surface and Medium, London 2013.

Pirrone, A., M. Beurton Aimar, N. Journet, "Papys-S-Net: A Siamese Network to Match Papyrus Fragments", in HIP 2019. Proceedings of the $5^{\text {th }}$ International Workshop on Historical Document Imaging and Processing, Sydney 2019, pp. 78-83.

Pleyte, W. and F. Rossi, Papyrus de Turin, Leiden 18691876.
Polis, S., “Linguistic Variation in Ancient Egyptian: An Introduction to the State of the Art (with Special Attention to the Community of Deir el-Medina)", in: J. Cromwell and E. Grossman (eds.), Scribal Repertoires in Egypt from the New Kingdom to the Early Islamic Period (Oxford Studies in Ancient Documents), Oxford 2017, pp. 60-88.

Polis, S., “The Scribal Repertoire of Amennakhte Son of Ipuy: Describing Variation Across Late Egyptian Registers", in: J. Cromwell and E. Grossman (eds.), Scribal Repertoires in Egypt from the New Kingdom to the Early Islamic Period (Oxford Studies in Ancient Documents), Oxford 2017, pp. 89-126.

Polis, S. and V. Razanajao, "Ancient Egyptian Texts in Context: Towards a Conceptual Data Model (the Thot Data Model - TDM)", BICS 59/2 (2016), pp. 24-41.

Ragazzoli, C., "Weak Hands and Soft Mouths: Elements of a Scribal Identity in the New Kingdom”, ZÄS 137 (2010), pp. 157-70.

Ragazzoli, C., "Lire en extraits : les manuscrits de miscellanées en Égypte ancienne, ou la lecture comme pratique créative", in: S. Morlet (ed.), Lire en extraits : histoire de la lecture et de la production des textes, de l'Antiquité à la fin du Moyen Âge, Paris 2015, pp. 11-28.

Ragazzoli, C., "Beyond Authors and Copyists: The Role of Variation in Ancient Egyptian and New Kingdom Literary Production”, in: T. Gillen (ed.), (Re)productive Traditions in Ancient Egypt: Proceedings of the Conference Held at the University of Liège, $6^{\text {th }}-8^{\text {th }}$ February 2013, (AegLeod 10), Liège 2017, pp. 95-126.

Ragazzoli, C., Scribes. Les artisants du texte en Égypte ancienne (1550-1000), Paris 2019.

Reggiani, N., Digital Papyrology I. Methods, Tools and Trends, Berlin 2017.

Roccati, A., "Scavi nel Museo Egizio di Torino, VII: tra i papiri torinesi”, OrAnt 14 (1975), pp. 243-53.

Roccati, A., "Un nuovo rotolo magico diviso tra le raccolte di Ginevra e Torino”, BSEG 7 (1982), pp. 91-94.

Roccati, A., Magica Taurinensia: il grande papiro magico di Torino e i suoi duplicati (AnOr 56), Roma 2011.

Ronneberger, O., Ph. Fischer and Th. Brox, "U-Net: Convolutional Networks for Biomedical Image Segmentation", MICCAI (2015), pp. 234-41, https://arxiv.org/ abs/1505.04597.

Štubňová, S., The Scribe of the Tomb Kenherkhepeshef in 19th Dynasty Deir el-Medina: The Life and Personality of an Individual and His Place in Society Based on the Evaluation of Textual, Iconographical and Archaeological Sources (unpublished MA thesis, Leiden University), Leiden 2013.

Štubňová, S., "A Prosopographic Analysis of the Known Kenherkhepshefs at Deir el-Medina and Some Observations on the Scribe Kenherkhepshef", GM 248 (2016), pp. 123-48.

Sweeney, D., "Friendship and Frustration: A Study in Papyri Deir el-Medina IV-VI”, JEA 84 (1998), pp. 101-22.

Töpfer, S., “The Turin Papyrus Online Platform (TPOP): An Introduction”, Rivista del Museo Egizio 2 (2018), pp. $1-11$.

Unter, S., "Transforming Fragments into Documents. Hieratic Papyri and the Use of Machine Learning", in A. Verbovsek, K. Gabler, and S. Bickel (eds.), Formen 
kultureller Dynamik: Impuls - Progession - Transformation. Beiträge des 10. Basler und Berliner Arbeitskreises Junge Aegyptologie (BAJA 10), 29.11.-01.12.2019, GOF
IV, Wiesbaden, submitted.

Valbelle, D., "Les ouvriers de la tombe" : Deir el-Médineh à l'époque ramesside (BdE 96), Cairo 1985. 